\title{
A POSSIBILIDADE DE ADOÇÃO DOS NEGÓCIOS JURÍDICOS PROCESSUAIS
} EM AÇÕES COLETIVAS

\author{
Carolina Dorta Cardoso ${ }^{1}$ \\ Luiz Fernando Bellinetti ${ }^{2}$
}

\section{RESUMO}

Analisa a possibilidade de adoção dos negócios processuais em ações coletivas. Deu-se ênfase na finalidade do instituto e na margem de negociação presente no ordenamento jurídico para interesses transindividuais. Utilizou-se dos entendimentos consolidados em relação ao Termo de Ajustamento de Conduta às convenções processuais. Observou-se que o objeto de negociação não será o direito indisponível, mas as circunstâncias para a efetiva tutela dos interesses transindividuais. Destacou-se a necessidade de que as convenções processuais se estendam às ações coletivas, como instrumento de acesso à justiça. Para obtenção dos resultados, adotou-se o método dedutivo através de pesquisa de legislação, doutrina e jurisprudência.

Palavras-chave: Negócios jurídicos processuais. Termo de ajustamento de conduta. Ações coletivas. Direitos indisponíveis. Acesso à justiça.

\section{THE POSSIBILITY OF ADOPTION THE CONTRACT PROCEDURE IN COLLECTIVE ACTIONS}

\begin{abstract}
Analyze the possibility of adoption the contract procedure in collective actions. Has verified the purpose of the institute and the space of negotiation present to the transindividual interests. Used the consolidated positions in relation to the Conduct Adjustment Term to the contract procedure. Has observed that the object of negotiation will not be the inalienable substantive law, but the circumstances for the effective protection of transindividual interests. Has included the need to extend the institute to the collective actions, as an instrument of access to justice. For the results, used the deductive method based on legislation, doctrine and jurisprudence research.
\end{abstract}

Keywords: Contract procedure. Conduct adjustment term. Collective actions. Inalienable rights. Acess to justice.

\footnotetext{
${ }^{1}$ Possui graduação em Direito pela Universidade Estadual de Londrina (2015). Mestranda em Direito Negocial pela Universidade Estadual de Londrina. Advogada regularmente inscrita na OAB - Paraná, com experiência em Direito Civil, Empresarial, Tributário e Administrativo.

2 Possui graduação em Direito pela Universidade Estadual de Londrina (1980), mestrado em Direito das Relações Sociais pela Universidade Estadual de Londrina (1985) e doutorado em Direito pela Pontifícia Universidade Católica de São Paulo (1997). Atualmente é professor associado da Universidade Estadual de Londrina. Tem experiência na área de Direito, com ênfase em Direito Processual Civil, atuando principalmente nos seguintes temas: interesses transindividuais, ações coletivas, ação civil pública, tutela jurisdicional e sentença.
} 


\section{INTRODUÇÃO}

Sob a égide do Código de Processo Civil de 1973, a doutrina divergia a respeito da possibilidade de adoção dos negócios jurídicos processuais. Hoje, com a vigência do novo Código de Processo Civil (Lei n. 13.105/2015) e da previsão de seu artigo $190^{3}$, não restam mais dúvidas quanto à possibilidade de sua utilização.

Aludido dispositivo legal possibilita que as partes, antes ou durante o processo, convencionem acerca de ônus, poderes, faculdades e deveres processuais ou conformem o procedimento às peculiaridades do litígio de forma atípica, ou seja, sem que haja a necessidade de enquadrarem o procedimento e as situações do processo em alguma das hipóteses elencadas na lei. Tal instituto tem como escopo a efetividade da tutela jurisdicional, de modo a possibilitar que processo e procedimento compatibilizem-se ao direito material invocado.

Todavia, o mesmo artigo 190 faz uma ressalva, ao limitar a adoção dos negócios processuais atípicos quando a demandar versar sobre direitos que admitam autocomposição. Nesse cenário, surge a questão de saber se, em ações coletivas, é possível a adoção das convenções processuais, na medida em que o objeto dessa espécie de demanda, em regra, diz respeito a direitos indisponíveis. Como se sabe, direitos indisponíveis, a princípio, não permitem autocomposição.

Diante do exíguo tempo de vigência do Código de Processo Civil, porém, questões como o espaço de utilização, efetividade e sucesso dos acordos processuais, permitem apenas uma análise inicial, já que, na prática, pouco se viu a respeito do instituto. Nesse cenário, assumir uma postura que defenda a adoção das convenções processuais em demandas coletivas, ante a limitação introduzida pelo artigo 190, impõe refutar os argumentos contrários sob um foco comparativo do instituto a outras modalidades semelhantes presentes no ordenamento jurídico, em que se visualiza uma margem de negociação em sede de interesses transindividuais.

Assim, em que pese a indisponibilidade presente nos interesses transindividuais, visualiza-se tal espaço de negociação quando se analisa o Termo de Ajustamento de Conduta

\footnotetext{
3 Art. 190. Versando o processo sobre direitos que admitam autocomposição, é lícito às partes plenamente capazes estipular mudanças no procedimento para ajustá-lo às especificidades da causa e convencionar sobre os seus ônus, poderes, faculdades e deveres processuais, antes ou durante o processo.
} 
(TAC). Do mesmo modo, observa-se que o objeto da ação coletiva não é o mesmo que o objeto dos negócios jurídicos processuais ou que do Termo de Ajustamento de Conduta, já que estes últimos referem-se a negociações atinentes às circunstâncias que melhor se coadunem à prestação de uma tutela efetiva do direito material.

Nesse viés, buscar-se-á, sem a pretensão de esgotar o assunto, analisar a possibilidade de adoção das convenções processuais em ações coletivas, ainda que estas versem sobre direitos indisponíveis, na medida em que o instituto consubstancia-se em um instrumento que facilita o acesso à justiça, eis que possibilita a compatibilização do procedimento e das situações do processo à tutela jurisdicional pretendida.

Para tal desiderato, ancorada na metodologia dedutiva, com base em pesquisa de legislação, doutrina e jurisprudência, objetiva-se a consecução do proposto através de uma análise inicial dos negócios jurídicos processuais e de sua finalidade centrada na efetiva prestação jurisdicional. Após, adentra-se ao espaço de negociação presente nos interesses transindividuais, visualizado através do Termo de Ajustamento de Conduta para, ao final, alocar-se na questão da possibilidade de adoção das convenções processuais em demandas coletivas.

\section{NEGÓCIOS JURÍDICOS PROCESSUAIS}

A adoção de um novo Código de Processo Civil pressupõe a construção de novas bases para o processo e seus respectivos institutos. É um momento de reestruturação de antigos valores e paradigmas. Parâmetros comumente seguidos dão espaço a novos preceitos, passíveis de caracterizar um cenário até então desconhecido.

O Código de Processo Civil de 2015 (Lei n. 13.105/2015), diferente do anterior, expressamente autoriza a adoção de convenções processuais, ou negócios jurídicos processuais atípicos. $\mathrm{O}$ instituto possibilita que as partes, antes ou durante o processo, e sem a necessidade de intervenção de um terceiro, convencionem a respeito da criação, modificação e extinção de situações processuais ou a alteração do procedimento. É o que prevê o artigo 190 do Código de Processo Civil, o qual autoriza que, quando a demanda versar sobre direitos que admitam autocomposição, as partes estipulem mudanças no procedimento e convencionem sobre ônus, poderes, faculdades e deveres processuais. 
A rigor, sob a égide do Código de Processo Civil de 1973, a doutrina não reconhecia o espaço para a autonomia da vontade das partes sobre matéria processual, o que ensejava rígida postura pela inadmissibilidade dos negócios jurídicos processuais. $\mathrm{O}$ argumento que respaldava essa assertiva traduzia o perfil público do processo civil, na medida em que a conduta das partes teria seus efeitos previstos em lei e, por tais razões, o formato padrão para o ato processual seria o ato jurídico estrito previsto em lei (CABRAL, 2016, p. 48). No ato processual em sentido estrito a vontade do agente apenas encontra a possibilidade de praticar ou não o ato previsto em lei, sendo vedado o controle de seu conteúdo. Nos negócios processuais, ou nas convenções processuais, o ato produz ou pode produzir os efeitos no processo escolhidos em função da vontade do sujeito que os pratica.

Na vigência do Código de Processo Civil de 2015, não restam mais dúvidas quanto à possibilidade das partes convencionarem sobre ônus, poderes, faculdades e deveres processuais, ou conformarem o procedimento à luz da autonomia da vontade. Isso porque o artigo 190 é enfático ao possibilitar que haja essa espécie de convenção pelos litigantes.

A regra esculpida em aludido artigo traz como previsão os negócios jurídicos processuais atípicos, ou seja, aqueles que possibilitam às partes estipularem acordos que não se encaixem nos tipos legais de convenções processuais e que, como finalidade, estruturem-se para atender as conveniências e as necessidades do litígio (CUNHA, 2015, p. 44).

Nesse viés, parece-nos correta a assertiva de que:

Ao que tudo indica, a pertinência e a relevância do instituto residem na possibilidade de as partes convencionarem o procedimento que seja mais adequado às peculiaridades de cada lide e se ajuste às necessidades dos litigantes, na busca de uma prestação jurisdicional mais eficaz à solução do litígio. (BELLINETTI; HATOUM; 2016, p. 49-71)

Essa inovação demonstra a preocupação pela legitimação da atividade jurisdicional, exercida mediante a participação efetiva dos litigantes (MARINONI; ARENHART; MITIDIERO, p. 434). Processo e procedimento devem se compatibilizar com o direito material e possibilitar que os participantes da relação processual possam adequá-los às peculiaridades da tutela pretendida.

Se, antes da fase instrumental do processo, a preocupação era apenas com sua autonomia frente ao direito material, agora, já se entende o processo enquanto ferramenta que deve desenvolver seu papel com efetividade, voltando-se para a realidade concreta e para as 
situações específicas carentes de tutela. Depreende-se, a partir disso, que a possibilidade de adoção dos negócios jurídicos processuais surge como reflexo desse cuidado em garantir efetividade à tutela jurisdicional.

Tal efetividade só se atinge quando a própria tutela jurisdicional volta-se para as especificidades do direito material. Sob esse foco, Luiz Guilherme Marinoni, Sérgio Cruz Arenhart e Daniel Mitidiero (2015, p. 129) elucidam que a tutela jurisdicional efetiva deve ser abarcada como direito fundamental previsto e garantido pela Constituição Federal, de modo que o legislador fique obrigado a instituir técnicas e procedimentos processuais aptos a permitirem a realização das tutelas pretendidas pelo direito material em foco.

Sabe-se, porém, que o atual cenário vivenciado pela sociedade contemporânea não permite que os procedimentos previstos nos textos legais adequem-se a toda e qualquer realidade. As vicissitudes e os problemas atuais, ao mesmo tempo em que se multiplicam de modo exponencial, diferem-se sobremaneira uns dos outros, a ponto de impossibilitarem que o legislador direcione as mesmas técnicas processuais para a solução de conflitos tão diferenciados, ao menos quando se busca, ao final, a efetividade dessa solução.

Nesse viés, Sérgio Cruz Arenhart (2003, p. 39) defende:

Para que o processo possa ser visto sob um prisma instrumental, na ótica acima lançada, é necessário que esteja apto a lidar com a vida cotidiana atual. É preciso, assim, que tenha condição de fazer frente aos direitos (e às relações sociais) vivenciadas na atualidade, o que é, evidentemente, incompatível com a disseminada tendência (quase uma necessidade vital), do jurista, de estabelecer dogmas válidos para todo lugar e tempo, imutáveis e intocáveis.

Assim, quando se analisam as convenções processuais, e a inovação por elas introduzida, realça-se essa preocupação em garantir efetividade para a tutela jurisdicional, sob o prisma de sua compatibilização com o direito material aduzido e as carências específicas do litígio. Nesse cenário, visualiza-se que, cada vez mais, os instrumentos processuais e a dogmática processual buscam meios de garantir que o acesso à justiça seja alcançado em sua plenitude.

Assim, essa inovação incorporada pelo ordenamento jurídico, ao passo em que demonstra uma finalidade em coadunar o processo e, por consequência, o procedimento, ao direito material em litígio, realça a ideia de que o acesso à justiça só é alcançado quando a prestação jurisdicional é prestada com efetividade. Não basta que os litigantes possam ter acesso ao Judiciário, é preciso que os instrumentos processuais garantam que o direito 
subjetivo possa ser tutelado efetivamente. Nesse cenário é que o negócio processual se enquadra, enquanto um meio de facilitar o acesso à justiça através de uma efetiva prestação jurisdicional.

Não há dificuldade, portanto, em garantir que a possibilidade das partes adequarem o processo e as consequentes situações nele previstas, às peculiaridades do direito material, tem como principal escopo a busca de uma solução compatível ao direito material invocado, à efetividade da tutela jurisdicional e, por consequência, à garantia do acesso à justiça.

A regra contida no artigo 190 é clara ao elucidar a permissão das partes convencionarem, de maneira atípica, com o escopo de ajustarem o processo às peculiaridades do litígio. Todavia, quando se analisa aludido texto, observa-se que este enfatiza tal possibilidade somente quando o processo versar sobre direitos que admitam autocomposição.

Em suma, a partir de uma leitura superficial do contido no artigo mencionado, poderse-ia afirmar pela impossibilidade de adoção de negócios jurídicos processuais em demandas que versarem sobre interesses indisponíveis, já que estes, a princípio, não admitiriam autocomposição e, portanto, não estariam abarcados pelo artigo 190 do Código de Processo Civil.

Nesse cenário, em sede de ações coletivas, cogitar-se-ia, também a princípio, pelo impedimento da adoção dos negócios processuais, justamente porque os interesses transindividuais, em regra, não permitem autocomposição.

Deve-se ter em mente, contudo, que o objeto dos negócios jurídicos processuais distancia-se do direito material postulado na demanda. $\mathrm{O}$ que se negocia mediante convenções processuais corresponde a ônus, poderes, deveres e sujeições processuais ou ao procedimento, a fim de viabilizar que a tutela jurisdicional seja prestada com maior efetividade. Não se cogita que o direito material indisponível, objeto da demanda, seja também objeto dos negócios jurídicos processuais.

Nesse cenário, surge a questão de saber se, quando a causa for atinente a interesses indisponíveis aduzidos em ações coletivas, a adoção dos negócios jurídicos processuais poderá acontecer, ainda que a norma processual limite sua utilização a demandas que versem sobre direitos autocomponíveis.

Antes, porém, de adentrar-se à questão da possibilidade ou impossibilidade de utilização das convenções processuais em demandas coletivas, é necessária uma análise a 
respeito da já existente e reconhecida margem de negociação em sede de interesses transindividuais, no conhecido Termo de Ajustamento de Conduta (TAC).

\section{A AUTOCOMPOSIÇÃO EM INTERESSES COLETIVOS ANALISADA À LUZ DO TERMO DE AJUSTAMENTO DE CONDUTA}

Quando se estudam os interesses coletivos lato sensu, os quais abarcam os difusos, os coletivos stricto senso e os individuais homogêneos, cuja proteção ocorre por meio de ações coletivas, tem-se a ideia principal de que estes são indisponíveis e, portanto, não abrangem qualquer margem de disposição por aqueles legitimados a defendê-los.

Isso porque, como se sabe, não são os próprios titulares do direito material os legitimados à sua defesa. Em razão da transindividualidade desses interesses, as leis do microssistema coletivo brasileiro elucidam, taxativamente, os entes que detém legitimidade para figurar no polo ativo da demanda coletiva. Assim, quando se está diante da defesa de interesses alheios, aduz-se pela indisponibilidade destes, em qualquer espécie de direito coletivo.

É nesse sentido que ensina Alexandre Amaral Gavronski (2016, p. 350):

Dai se concluir que os direitos coletivos (lato sensu) são indisponíveis pelos legitimados coletivos, independente da natureza desses direitos, ou seja, se materialmente disponíveis ou se indisponíveis pelo próprio titular. Não se trata, pois, de (in)disponibilidade dos direitos em si, mas de uma indisponibilidade pelos legitimados a defendê-los.

Justamente em face do caráter indisponível que reveste o objeto das ações coletivas, depreende-se, em uma análise superficial, pela impossibilidade de negociação nessa espécie de demanda, sob a premissa de que a autocomposição implicaria na disposição dos direitos materiais indisponíveis. A defesa, nesse sentido, é pela impossibilidade de serem praticados quaisquer atos que, direta ou indiretamente, importem na disposição do direito material coletivo (JELINEK, 2016, p. 237).

É nesse ponto, em especial, que reside a confusão terminológica. Alexandre Amaral Gravonski (2016, p. 351) sustenta que não se pode confundir a autocomposição ou a negociação em ações coletivas, com a transação prevista nos artigos 840-850 do Código Civil. A negociação nas demandas coletivas não importa, em regra, na disposição do direito material, ao contrário do que acontece com a transação. Em suas palavras, "a negociação em 
tutela coletiva não comporta, como na transação, concessões sobre o conteúdo dos direitos (renúncias)".

Na ação coletiva, é cristalino não caber ao ente legitimado à defesa dos interesses transindividuais em juízo, a disposição dos direitos materiais. Todavia, isso não impede que certas concessões de ordem procedimental se realizem, a fim de que a tutela jurisdicional possa ser prestada com maior efetividade. Não se deve esquecer, como salienta Cândido Rangel Dinamarco (2009, p. 112), que o acesso à ordem jurídica justa só é atingido através do recebimento efetivo da prestação jurisdicional.

Embora os interesses coletivos revistam-se de nítida indisponibilidade, "alguns instrumentos legais permitem uma margem de negociação no que tange ao tempo e o modo de cumprimento das obrigações legais" (CABRAL, 2016, p. 326), de modo a ser possível concluir, em um primeiro momento, pela possibilidade de negociação em sede de interesses coletivos. Essa margem é visualizada quando se analisa o Termo de Ajustamento de Conduta (TAC).

O denominado Termo de Ajustamento de Conduta tem autorização na Lei $n^{\circ} 7.347$ de 1985 , em seu artigo $5^{\circ}, \S 6^{\circ}$, o qual especifica a possibilidade dos entes legitimados tomarem dos interessados compromissos de ajustamento de conduta, mediante cominações, cuja eficácia será de título executivo extrajudicial. O escopo do TAC é, assim, tutelar com maior efetividade o interesse transindividual, adotando-se especificações de tempo, modo e lugar para a efetivação desses interesses.

Embora o ajustamento seja uma atividade extrajudicial, que acontece, portanto, anteriormente à eventual ação coletiva, a negociabilidade nele presente realça a possibilidade conferida pelo ordenamento jurídico a soluções negociadas em matéria de interesses indisponíveis.

No Termo de Ajustamento de Conduta reconhece-se a existência de um fato determinado, consubstanciado em uma ação ou omissão, que pode causar, ou já ter ocasionado, a lesão aos interesses transindividuais. Após, o responsável pelo ato ou omissão pactua junto ao ente legitimado a defender os interesses coletivos, a fim de evitar o dano ou repará-lo integralmente. "No ajuste de conduta, o obrigado assume o cumprimento de obrigações para afastar a incidência do que se convenciona chamar de responsabilidade civil" (RODRIGUES, 2002, p. 110). 
Em que pese o termo seja firmado através de negociação, o direito material coletivo não pode ser objeto do ajuste. Nesse sentido, Geisa de Assis Rodrigues (2002, p. 121) ressalta:

\begin{abstract}
Ao mesmo passo não pode a aplicação desses instituto importar de forma alguma em limitação do acesso à justiça de direito transindividual, ou de direito individual. Sendo, em verdade, esta a sua medida de justiça. Assim, no compromisso de ajustamento de conduta não pode haver disposição sobre o dever de respeitar os direitos transindividuais. Não pode haver qualquer tipo de renúncia ao direito objeto do compromisso, nem qualquer tipo de concessão sobre o efetivo atendimento do direito. Em termos práticos essa medida de justiça será aferida quando o ajuste propiciar que se obtenha uma proteção mais efetiva ou pelo menos idêntica ao que se obteria em juízo.
\end{abstract}

Na prática, o TAC tem se mostrado como um efetivo instrumento de concretização dos interesses transindividuais, porquanto possibilita que os entes públicos legitimados à propositura da demanda coletiva, convencionem a respeito da melhor forma em que se dará a reparação do dano, antes que a ação coletiva se instaure. Leia-se, a convenção não tem como objeto o direito material, mas o melhor caminho para se alcançar a efetiva tutela desse direito.

Conforme aduzido, a autocomposição em ações coletivas difere-se da transação, na medida em que esta última tem como objeto a disposição do próprio direito material, enquanto a negociabilidade acontece a fim de propiciar as melhores circunstâncias para a efetividade da tutela jurisdicional. Alexandre Amaral Gavronski, nesse sentido, aduz (2016, p. 356) que "as concessões do legitimado coletivo não versam sobre o conteúdo do direito propriamente dito, mas sobre as condições em que se dará sua implementação".

Ana Luiza de Andrade Nery (2012, p. 198), porém, faz uma ressalva quanto a esse espaço de negociabilidade, ao defender:

O espaço transacional possível no compromisso de ajustamento de conduta não se refere a aspectos meramente formais do negócio (...). As partes poderão entabular, no compromisso, direitos e obrigações para ambas as parte, que lhe confiram caráter de máxima eficiência para os fins pretendidos pelos celebrantes. Assim, poderão ser previstas obrigações a serem cumpridas tanto pelo particular como pela entidade pública que celebra o ajustamento.

Cabe ressaltar, contudo, que essa possibilidade das partes convencionarem acerca de direitos e obrigações recíprocas, embora possível no Termo de Ajustamento de Conduta, não pode macular o direito material aduzido, já que não é possível dispensar-se a satisfação do interesse transindividual fruto de eventual ação coletiva, mas tão somente regular o modo em que a reparação dos prejuízos irá acontecer (DIDIER JR., 2016, p. 306), ainda que isso implique em concessões e obrigações recíprocas das partes. 
Frisa-se, ademais, que a negociabilidade em ações coletivas pode ser vislumbrada também, na utilização de meios alternativos de solução de conflitos em matéria de direitos transindividuais. Nesse sentido, Ada Pellegrini Grinover (2006, p. 252) ressalta que, embora os direitos coletivos sejam indisponíveis, há certa parcela de disponibilidade que permite uma margem de negociação. Embora a autora tenha se referido à possibilidade de adoção da arbitragem em certos conflitos de direitos ambientais, raciocínio similar pode ser adotado na análise do Termo de Ajustamento de Conduta. Ainda que, por óbvio, não se permita que o ajustamento disponha sobre o interesse transindividual violado, é possível, e aconselhável, a adoção de medidas ajustadas no TAC, buscando sempre o melhor meio para a garantia dos interesses transindividuais.

O que se percebe, desse modo, é que, embora os interesses metaindividuais estejam protegidos pelo manto da indisponibilidade, o ordenamento jurídico autoriza, em certas ocasiões, a negociabilidade em sede coletiva. $\mathrm{O}$ escopo, ao final, é o mesmo: dar guarida à tutela dos interesses transindividuais.

\section{A POSSIBILIDADE DE ADOÇÃO DOS NEGÓCIOS JURÍDICOS PROCESSUAIS EM AÇÕES COLETIVAS COM BASE NA ANÁLISE COMPARATIVA PROPOSTA.}

Em um primeiro momento, cabe elucidar que o microssistema processual brasileiro para as ações coletivas permite que as disposições do Código de Processo Civil sejam aplicadas ao processo coletivo, ainda que aquele não trate, especificamente, dessa modalidade de processo. Tal autorização pode se verificar no artigo 19 da Lei da Ação Civil Pública (Lei $\mathrm{n}^{\circ} 7.347$ de 1985), bem como no artigo 90 do Código de Defesa do Consumidor (Lei n ${ }^{\circ} 8.078$ de 1990), que elucidam ser possível a aplicação do Código de Processo Civil, naquilo em que não contrariar aludidos dispositivos legais. A fim de incorporar autorizações nesse sentido, o Código de Processo Civil de 2015, em seu artigo 1.046, $\S 4^{\circ}$, especifica que as remissões contidas em outras leis acerca do Código de Processo Civil de 1973, passam a referir-se às que lhe são correspondentes no novo código.

A regra esculpida pelo artigo 190 do Código de Processo Civil, ao mesmo tempo em que inova, por possibilitar a adoção de convenções processuais atípicas, limita, ao aduzir pela viabilidade dos acordos somente quando a demanda versar sobre direitos que admitam autocomposição. Nesse viés, torna-se difícil, em um primeiro momento, afirmar pela 
possibilidade de adoção dos negócios processuais em ações coletivas, já que seu objeto é a tutela de direitos indisponíveis. Como o próprio nome alude, direitos indisponíveis não são passíveis de disposição.

Tal assertiva, conjugada ao limite imposto pelo artigo 190 do Código de Processo Civil, vem ensejando a afirmativa de que "para que seja possível a convenção processual, o objeto do processo - isto é, o direito material a ser debatido ou em debate - deve ser autocomponível” (GAJARDONI; DELLORE; ROQUE; OLIVEIRA, 2015, p. 379).

Não se pode, contudo, assumir uma posição radical pela impossibilidade de utilização das convenções processuais em ações coletivas, na medida em que, como já verificado, a autocomposição e a negociabilidade podem, sim, estar presentes na tutela dos interesses transindividuais. A transação envolvendo o direito material não deve ser confundida com a negociabilidade em matéria coletiva. Enquanto a transação circunda a disposição de direitos, a negociabilidade em sede coletiva envolve a construção, em conjunto das partes, de caminhos mais eficazes para a efetiva tutela do direito coletivo.

É justamente nesse ponto, a similitude existente entre os negócios jurídicos processuais e o Termo de Ajustamento de Conduta.

Embora o primeiro tenha como objetivo a maior efetividade da tutela jurisdicional e o segundo busque dar guarida aos interesses coletivos antes de instaurada a demanda, certo é que a finalidade de ambos coaduna-se à busca da melhor solução para a tutela do direito material, ainda que somente nos negócios processuais essa tutela possa ser classificada como jurisdicional.

Em face, precisamente, da finalidade em prestar efetivamente o direito material coletivo, torna-se evidente que, tanto os negócios jurídicos processuais, quanto o Termo de Ajustamento de Conduta, não têm o escopo de dispor dos direitos indisponíveis. Se o objetivo é exatamente resguardar o direito material, não há sentido afirmar que a negociabilidade presente nos dois institutos irá macular esse direito.

O propósito das convenções processuais é unicamente o desenvolvimento do processo judicial que passa a ser moldado sob a luz da autonomia privada. Assim, mostra-se "evidente que esses pactos nada têm a ver com eventuais atos de disposição que interferem sobre o direito material” (MARINONI; ARENHART; MITIDIERO, 2015, p. 525).

Aduzir pela possibilidade de negociação em sede coletiva envolve a necessidade de uma análise a respeito do objeto da negociação. Ou seja, é preciso verificar, em especial nos 
negócios processuais, qual o direito objeto do acordo, se direito material ou se direito processual e, a partir disso, elucidar sobre qual deles recai a indisponibilidade.

Quanto ao Termo de Ajustamento de Conduta, não é difícil aduzir pela impossibilidade de que seu objeto seja o direito material indisponível. Conforme elucidado, as concessões nele presentes não envolvem o direito coletivo, mas as melhores condições para sua efetivação (GAVRONSKI, 2016, p. 356), já que o ente legitimado à sua realização não detém o direito de dispor dos interesses transindividuais.

Geisa de Assis Rodrigues (2002, p. 175), ao realizar minucioso estudo a respeito do TAC, advertiu que seu objeto não pode dispensar as obrigações necessárias para a efetiva satisfação do direito, ou seja, o compromisso deve ser um caminho a alcançar tudo que seria possível obter mediante a procedência da ação coletiva. Assim, seu objeto não deve versar sobre o direito material coletivo, mas sobre as condições para melhor efetivar sua proteção. Em suma, ainda que o ajustamento aconteça em sede pré-processual, a finalidade por ele buscada assemelha-se à prestação jurisdicional e, por versar a respeito de interesses indisponíveis, os legitimados a firmá-lo, não podem dispor a respeito do interesse transindividual objeto de reparação.

Por outro lado, diante dos negócios jurídicos processuais, a limitação imposta pela norma processual, em seu artigo 190, deixa dúvidas quanto ao objeto do acordo, já que só autoriza sua adoção quando a demanda versar sobre direitos que admitam autocomposição. Se a regra veda a utilização quando o objeto do processo for direito material indisponível, seria lógico aduzir que o objeto das convenções processuais é justamente esse direito revestido de indisponibilidade.

Todavia, esse entendimento não deve prevalecer.

Quando se analisa mencionada vedação, não se deve estabelecer confusão a respeito do que é objeto litigioso da demanda e do que é objeto dos negócios jurídicos processuais. A amplitude das convenções processuais é adstrita ao processo civil. Logo, o objeto do acordo deve se restringir à conduta das partes no processo jurisdicional, já que é sobre ele que os efeitos jurídicos pretendidos no negócio processual irão incidir. Uma coisa é o objeto da convenção, outra, o objeto da demanda.

Por óbvio que, determinadas situações, ainda que envolvam somente direitos processuais, não poderão ser objeto de convenção. Isso acontece, não porque o direito objeto da demanda é indisponível, mas sim porque o próprio direito processual não é passível de 
disposição. É o que acontece, por exemplo, em temas como reexame necessário e intervenção obrigatória do Ministério Público, os quais, embora não se relacionem diretamente ao direito material, mostram-se como indisponíveis na seara do processo civil (CUNHA, 2014, p. 94). O mesmo ocorre na hipótese dos acordos processuais que violem direitos fundamentais, tais como o direito ao contraditório ou à isonomia (MARINONI; ARENHART; MITIDIERO, 2015, p. 529).

Evidente que, eventual disposição em acordos processuais, nesses casos específicos, poderá acarretar a invalidação da convenção, com fundamento na ilicitude de seu objeto. Porém, quando o objeto do acordo versar sobre direitos processuais passíveis de disposição, não há que se invalidar o negócio processual, ainda que o objeto da demanda referir-se a direito material indisponível.

Os acordos processuais podem, inclusive, aumentar o grau de proteção conferido pelo ordenamento aos bens indisponíveis, como ocorre na hipótese de, em ações coletivas, definir-se um prazo maior para a prática de determinado ato em favor da coletividade, ou a fixação de um foro competente para a colheita de provas que seja mais eficiente ou mais próximo em termos geográficos, da comunidade lesada (CABRAL, 2016, p. 329).

Nesse cenário, o que se verifica é que o ordenamento jurídico já possibilita a negociabilidade em interesses coletivos, na medida em que confere aos legitimados à sua defesa, tomar compromissos, com força de título executivo, daqueles responsáveis civilmente pela violação dos direitos coletivos, através dos Termos de Ajustamento de Conduta.

Ainda que o TAC se realize de forma extraprocessual, seu objetivo é o mesmo buscado pelos negócios jurídicos processuais, qual seja, tutelar com maior efetividade o direito coletivo. Logo, não se deve aduzir, de modo radical, pela impossibilidade de adoção dos acordos processuais em ações coletivas, sob a justificativa da indisponibilidade do interesse, justamente porque, em casos similares, há margem de negociação expressamente autorizada pelo legislador, ainda que o direito seja indisponível.

A finalidade dos acordos processuais é conformar o procedimento às peculiaridades exigidas pelo direito material, de modo a tornar mais efetiva a prestação jurisdicional e garantir meios para que o acesso à justiça possa ser atingido em sua plenitude. Necessária, desse modo, uma interpretação ampliativa do artigo 190 do Código de Processo Civil, a fim de viabilizar a adoção de convenções processuais em ações coletivas, na medida em que o objeto do acordo, diferente do objeto da demanda, não é o interesse material indisponível. 
Em outro giro, verifica-se que os acordos processuais conectam-se, diretamente, a princípios constitucionais como acesso à justiça e tutela jurisdicional efetiva. Quando Mauro Cappelletti e Bryant Garth (2002, p. 43) estudam o tema acesso à justiça, elucidam que um sistema jurídico atento a esse princípio deve ser igualmente acessível a todos e ao mesmo tempo produzir resultados que sejam justos. De modo contundente, afirmam que o acesso à justiça, aludido a direito fundamental pelos ordenamentos jurídicos, deve ser ponto central no estudo e desenvolvimento da ciência processual.

Mauro Vasni Paroski (2006, p. 228), por sua vez, afirma que acesso à justiça é não só ter acesso ao Poder Judiciário, mas obter concretamente a tutela jurisdicional quando se tem razão, com a necessidade de que esta seja adequada, tempestiva e eficaz. Nesse sentido, Dinamarco $(2009$, p. 173) leciona que só tem acesso à ordem jurídica justa, quem recebe justiça, sendo esta última entendida como a possibilidade de participação no processo, participação adequada do juiz e, por fim, recebimento efetivo da prestação jurisdicional.

Os meios conferidos pelo Estado para a solução de conflitos, no entanto, tem se mostrado deficientes a prestar a tutela jurisdicional de forma eficiente e tempestiva e, por consequência, culminando em uma deficiência também na garantia de acesso à justiça e da tutela jurisdicional efetiva que dele decorre.

Como o escopo dos negócios jurídicos processuais é, em primordial, garantir que o procedimento e as situações do processo compatibilizem-se à situação específica do direito material e, assim, possam conferir uma prestação jurisdicional efetiva, é possível inferir que sua adoção pelo ordenamento jurídico é um reflexo dessa preocupação em garantir aos jurisdicionados o acesso à justiça enquanto direito fundamental.

Deixar, portanto, que os acordos processuais se realizem somente em ações individuais, em detrimento dos interesses coletivos, é andar na contramão das garantias processuais fundamentais conferidas pela Constituição Federal, tais como acesso à justiça e tutela jurisdicional efetiva, as quais devem se compatibilizar com qualquer espécie de demanda, quer envolva interesses individuais, quer se relacione aos coletivos lato sensu.

\section{CONCLUSÃO}

Os negócios jurídicos processuais são uma inovação introduzida pelo atual Código de Processo Civil. A possibilidade das partes conformarem o procedimento e as situações 
processuais às peculiaridades do direito material, na busca de uma efetiva prestação jurisdicional, demonstra uma preocupação em garantir que o processo atinja sua finalidade. $\mathrm{O}$ artigo 190, porém, se analisado superficialmente e interpretado de maneira literal, não permitiria a adoção do instituto em demandas que versem sobre direitos indisponíveis, já que estes, em regra, não autorizam autocomposição. Assim, a princípio, não seria possível a utilização de convenções processuais em ações coletivas.

Tal postura, no entanto, não deve ser assumida. O legislador, ao limitar a adoção das convenções processuais a demandas relativas a direitos autocomponíveis, o fez, na tentativa de proteger os chamados direitos indisponíveis os quais, como o próprio nome aduz, não dão margem à disposição.

Em sede de interesses transindividuais, todavia, embora em regra estejamos diante de direitos indisponíveis, o ordenamento jurídico confere certa liberdade de negociação, permitindo que os entes expressamente autorizados convencionem a respeito das circunstâncias em que a tutela coletiva será prestada. No presente estudo, que não tem a pretensão de esgotar o assunto, verificou-se essa possibilidade já reconhecida em relação aos Termos de Ajustamento de Conduta (TAC).

Através desses ajustamentos, ainda que diante de interesses transindividuais que não autorizam disposição, é possível que as partes acordem questões como tempo, modo e lugar em que se dará a reparação do dano, com o escopo de garantir uma efetiva tutela do direito material coletivo. O que se percebe, desse modo, é que através do Termo de Ajustamento de Conduta, negocia-se a respeito das melhores condições para a prestação do direito material, nunca sobre o próprio direito material, já que, como se viu, este não é passível de negociabilidade.

De modo bastante similar, só que, desta vez, inserido na jurisdição, os negócios jurídicos processuais também não têm como escopo a negociação do direito material, mas as questões referentes ao processo e, em consequência, ao procedimento. Deve-se ter em mente que os efeitos jurídicos das convenções processuais limitam-se ao espaço do processo e, por isso, seu objeto também abarca questões envolvendo o direito processual e não o direito material.

Conforme aduzido, não se deve estabelecer confusão a respeito do que é objeto litigioso da demanda e do que é objeto dos negócios jurídicos processuais. Uma coisa é o objeto da demanda, que, no caso das ações coletivas, é o direito material indisponível. Outra é 
o objeto das convenções processuais, que se limita a questões relativas ao processo e ao litígio, sem macular, a princípio, o direito material invocado.

Por óbvio que, versando a negociação a respeito de direito processual indisponível ou princípios processuais constitucionais, sua invalidação será necessária. Isso deve acontecer, porém, não porque a causa é atinente a direito indisponível, mas porque o próprio interesse processual objeto de disposição estará revestido pela indisponibilidade.

Assim, é preciso que se faça uma interpretação adequada do esculpido no artigo 190 do Código de Processo Civil, a fim de que seja possível a adoção das convenções processuais em ações coletivas. Tanto em face da já presente margem de negociação em interesses transindividuais visualizada, em especial, nos Termos de Ajustamento de Conduta, como em razão do objeto da demanda não poder ser confundido com o objeto dos negócios processuais.

Desse modo, ancorado na ideia de que o acesso à justiça não se resume ao acesso ao Poder Judiciário, mas à efetiva prestação jurisdicional, bem como a partir do entendimento de que os negócios jurídicos processuais têm, como principal escopo, adequar o procedimento ao direito material e à tutela jurisdicional pretendida, enquanto instrumento que garanta uma efetiva prestação jurisdicional, torna-se cristalino concluir que os acordos processuais têm como qualidade facilitar o acesso à justiça em sua plenitude.

Logo, não é pertinente que sua utilização se resuma à tutela dos interesses individuais, porquanto os interesses transindividuais, em face de sua magnitude e importância, também merecem desfrutar dos instrumentos processuais que garantam pleno acesso à justiça, não só em termos de participação junto ao órgão jurisdicional, como também e, em especial, através da efetiva prestação jurisdicional.

Somente assim o negócio jurídico processual será adotado em sua integralidade, garantindo que a conformação do procedimento ao direito material e, por consequência, a efetividade da prestação jurisdicional e do acesso à justiça atinjam, também, os interesses transindividuais.

\section{REFERÊNCIAS BIBLIOGRÁFICAS}

ARENHART, Sérgio Cruz. Perfis da tutela inibitória coletiva. São Paulo: Editora Revista dos Tribunais, 2003. 
BELLINETTI, Luiz Fernando; HATOUM, Nida Saleh. Aspectos relevantes dos negócios jurídicos processuais previstos no art. 190 do CPC/2015. In: Revista de Processo: RePro, São Paulo, v. 41, n. 260, p. 49-71, out. 2016.

BOMFIM, Daniela Santos. As legitimidade extraordinária de origem negocial. In: CABRAL, Antonio do Passo; NOGUEIRA, Pedro Henrique Pedrosa (coords). Negócios Processuais. Salvador: Juspodivm, 2015.

CABRAL, Antonio do Passo. A resolução no 118 do Conselho Nacional do Ministério Público e as Convenções Processuais. In: CABRAL, Antonio do Passo; NOGUEIRA, Pedro Henrique Pedrosa (coords). Negócios Processuais. Salvador: Juspodivm, 2015.

.Convenções processuais. Salvador: JusPodivm, 2016.

CAPPELlETTI, Mauro; GARTH, Bryant. Acesso à justiça. Trad. de Ellen Gracie Northfleet. Porto Alegre: Sergio Antonio Fabris, 2002.

CUNHA, Leonardo Carneiro da. Negócios jurídicos processuais no processo civil brasileiro. Texto apresentado para o I Congresso Peru-Brasil de Direito Processual, em Lima, no Peru, em novembro de 2014. Disponível em: http://ufpe.academia.edu/LeonardoCarneirodaCunha. Acesso em: 14 de março de 2017.

Negócios jurídicos processuais no processo civil brasileiro. In: CABRAL, Antonio do Passo; NOGUEIRA, Pedro Henrique Pedrosa (coords). Negócios Processuais. Salvador: Juspodivm, 2015.

DIDIER JR., Fredie; NOGUEIRA, Pedro Henrique. Teoria dos fatos jurídicos processuais. Salvador: JusPodivm, 2009.

DINAMARCO, Cândido Rangel. Instituições de direito processual civil. 6. ed. São Paulo: Malheiros, 2009. v. 2.

GAJARDONI, Fernando Fonseca; DELlORE, Luiz; ROQUE, Andre Vasconcelos; OLIVEIRA JR., Zulmar Duarte. Teoria geral do processo - comentários ao CPC de 2015 parte geral. São Paulo: Método, 2015.

GAVRONSKI, Alexandre Amaral. Autocomposição no novo CPC e nas ações coletivas. In: DIDIER JR., Fredie; ZANETI JR., Hermes (coord.). Coleção Repercussões no Novo CPC: processo coletivo. Salvador: Juspodivm, 2016.

GRINOVER, Ada Pellegrini. Conferência sobre arbitragem na tutela dos interesses difusos e coletivos. Revista de Processo. São Paulo: RT, n. 136, jun/2006, p. 252.

JELINEK, Rochelle. A legitimação para celebração de compromissos de ajustamento de conduta e para sua execução. In: DIDIER JR., Fredie; ZANETI JR., Hermes (coord.). Coleção Repercussões no Novo CPC: processo coletivo. Salvador: Juspodivm, 2016.

MARINONI, Luiz Guilherme; ARENHART, Sérgio Cruz; MITIDIERO, Daniel. Novo curso de processo civil: teoria do processo civil. v. 1. São Paulo: Revista dos Tribunais, 2015. 
NERY, Ana Luíza de Andrade. Compromisso de ajustamento de conduta. 2. ed. São Paulo: Editora Revista dos Tribunais, 2012.

PAROSKI, Mauro Vasni. Do direito fundamental de acesso à justiça. In: Scientia Iuris, Londrina, v. 10, p. 225-242, 2006.

RODRIGUES, Geisa de Assis. Ação civil pública e termo de ajustamento de conduta. Rio de Janeiro: Forense, 2002. 